J. Clin. Chem. Clin. Biochem.

Vol. 24, 1986, pp. 199-203

(C) 1986 Walter de Gruyter \& Co.

Berlin - New York

\title{
Thyrotropin Enzyme-Immunoassay in Dried Blood Spots: A Spectrophotometric Method for Neonatal Thyroid Screening $\left.{ }^{1}\right)^{2}$ )
}

\author{
By T. Torresani, Qiu Qing ${ }^{3}$ ) and Ruth Illig \\ Department of Pediatrics, University of Zürich, Switzerland
}

(Received July 24/October 25, 1985)

Summary: We describe an enzyme-immunoassay with photometric endpoint determination, suitable for the measurement of thyrotropin (TSH) in dried blood spotted on filter paper. Using reagents of a commercially available test kit provided for the measurement of thyrotropin in $200 \mu \mathrm{l}$ serum, we have adapted the method to the determination of thyrotropin in blood spots containing ca. $10 \mu \mathrm{l}$ blood. This was achieved by prolongation of the assay time from 3 to 20 hours, and by increasing the amount of enzyme-antibody complex. Precision and sensitivity of the blood spot assay are comparable to those of our in-house thyrotropin RIA, and the RIA/EIA correlation coefficient is $0.987(n=150)$. The advantages of EIA are the simplicity of the photometric end point determination (although strict time control has to be observed in order to avoid drifts in results), the long stability of reagents, and the non-isotopic label. The method therefore appears to be a suitable alternative to thyrotropin RIA for the determination of thyrotropin in neonatal thyroid screening.

Thyrotropin-Enzym-Immunoassay in getrockneten Blutstropfen: Eine spektrophotometrische Methode für das neonatale Schilddrüsen-Screening

Zusammenfassung: Wir beschreiben einen Enzym-Immunoassay mit photometrischer Endpunkt-Bestimmung, der zur Messung des Thyrotropins (TSH) aus auf Filterpapier getrockneten Blutstropfen geeignet ist. Es wurden Reagenzien aus einem im Handel erhältlichen Kit zur Bestimmung des Thyrotropins in $200 \mu l$ Serum verwendet, und die Mèthöde wurde zur Bestimmung von Thyrotropin aus getrockneten Blutstropfen, enthaltend etwa $10 \mu \mathrm{l}$ Blut, adaptiert. Dies wurde durch Verlängerung der totalen Inkubationszeit auf 20 Stunden und durch Erhöhung der Konzentration des Antikörper-Enzym-Komplexes erzielt. Präzision und Empfindlichkeit des Asșays sind mit denen unserer eigenen RIA-Methode vergleichbar, und der Korrelationskoeffizient zwischen RIA und EIA beträgt 0,987 $(n=150)$. Die Vorteile des EIA liegen in der Einfachheit der photometrischen Endpunkt-Messung, obschon der Pipettierzeit große Aufmerksamkeit geschenkt werden muß, in der langen Haltbarkeit der Reagenzien und in der nicht-isotopischen Markierung. Alle diese Eigenschaften machen aus diesem Test eine unserer Meinung nach sehr geeignete Alternative zum Thyrotropin̈-RIA für das neonatale Schilddrüsen-Screening.

\section{Introduction}

Neonatal thyroid screening on a large scale is usually performed in dried blood spots by radioimmunoassays of thyrotropin and/or $\mathrm{T}_{4}(1,2)$. These assays have proved to be reliable, but the method has several inherent disadvantages such as the instability of reagents, the legal requirements for handling radio- active substances, and the cost of disposing of radioactive vaste. Therefore the development of alternative methods was highly desirable. In 1983 an enzyme-

1) Presented in part at the $7^{\text {th }}$ International Congress of Endocrinology, Quebec 1984.

2) Supported by the Swiss National Science Foundation, Grant No. 3.906.0.83 and by Boehringer Mannheim.

3) Visiting Fellow from Beijing, People's Republic of China. 
immunoassay with fluorimetric end point reading was described, which could be applied to the determination of thyrotropin and $T_{4}$ in dried blood spots, after elution from filter paper (3).

Recently an enzyme-immunoassay with photometric end point reading, suited to the determination of serum thyrotropin has become commercially available. The possibility of carrying out an enzyme-immunoassay, using a simple photometer, available in almost every laboratory, instead of a more expensive and complicated fluorometer, led us to adapt this method to the measurement of thyrotropin in dried blood spots, with the aim of applying it to mass screening for congenital hypothyroidism (4).

Other authors, using the same reagents, have also modified the thyrotropin EIA, with the aim of increasing its sensitivity, to obtain a thyrotropin assay which could be used for the discrimination between eu- and hyperthyroid plasma thyrotropin levels $(5,6)$.

\section{Materials and Methods}

Sample collection

Capillary blood was obtained by heel prick, spotted on filter paper (Schleicher \& Schüll No. 2992) and dried at room temperature. The samples were kept in a plastic box at $4{ }^{\circ} \mathrm{C}$ until analysed.

\section{Blood spot thyrotropin EIA}

For the determination of thyrotropin in dried blood by enzymeimmunoassay, the 'Enzymun-Test-TSH' Kit (Boehringer Mannheim) was used after modifications, as described in the result section.

This assay system is based on a sandwich technique which uses monoclonal anti- $\beta$-thyrotropin antibodies coupled to the wall of the reaction tube and polyclonal anti- $\alpha$-thyrotropin antibodies coupled to horseradish peroxidase as the label. The reaction end point is read spectrophotometrically at $405 \mathrm{~nm}$ by monitoring the colour change of the chromogen 2,2'-azino-di-(3-ethylbenzthiazoline-6-sulphonate) (ABTS) in the presence of $\mathrm{H}_{2} \mathrm{O}_{2}$. The reagents are stable fore 12 months when stored at $4^{\circ} \mathrm{C}$. All reagents were used as supplied by the manufacturer of the kit.

\section{Preparation of thyrotropin standards in blood}

Concentrated thyrotropin standard preparation MRC 68/38 in $0.05 \mathrm{~mol} / 1$ phosphate buffer, $\mathrm{pH} 7.4$ containing bovine serum albumin $(50 \mathrm{~g} / \mathrm{l})$, was diluted with blood from an adult euthyroid donor to working concentrations of $5,10,20,50$ and 100 $\mathrm{mU} / 1$ blood. The volume of the added standard solutions never exceeded $5 \%$ of the blood volume. These standard solutions were spotted on filter paper (Schleicher \& Schüll No. 2992), dried at room temperature and stored in a plastic box at $4{ }^{\circ} \mathrm{C}$ until used.
Comparison of blood spot thyrotropin RIA with thyrotropin EIA

To assess the validity of the thyrotropin EIA results, thyrotropin was determined radioimmunologically in dried blood spots with the RIA as used in our laboratory for neonatal thyroid screening (1). For this purpose samples collected routinely for the neonatal thyroid screening were analysed by RIA as well as by EIA.

\section{Statistics}

Assay precision and sensitivity were calculated according to Rodbard (7). The significance of differences was estimated using the Wilcoxon signed rank test for paired samples.

\section{Results}

\section{Preliminary studies}

In our first experiments we tested whether the filter paper discs could stay in the tubes throughout the assay, as in our thyrotropin RIA (1), or whether they had to be removed prior to the enzyme reaction. We found that in the presence of the filter paper, the absorbance of the zero standard reached values of 1.5 or higher, making further absorbance readings impossible. We had therefore to remove the filter paper discs from the assay tubes after the first incubation.

\section{Duration of incubation}

The original procedure for the thyrotropin EIA calls for 3 incubation steps of one hour each, using a sample of $200 \mu \mathrm{l}$ serum. In the blood spot assay we use samples of $10 \mu \mathrm{l}$ dried blood, corresponding to approximately $5 \mu$ l of plasma. For this and for other practical reasons (e. g. large sample series), we have extended the total incubation time to approximately 20 hours. The first step consisted of an overnight $(15 \mathrm{~h})$ incubation at $4^{\circ} \mathrm{C}$. From our experience with blood spot RIA (1) we knew that thyrotropin elutes almost completely from filter paper during this time. All further incubation steps were performed at room temperature. The time of the incubation with peroxidase-antibody complex was increased from 1 to 3 hours, and the time of the incubation with ABTS was changed from 1 to 2 hours. These increases in incubation time did not affect the absorbance in the samples with basal thyrotropin concentrations, but resulted in an increase of absorbance at higher thyrotropin concentrations. The increment in absorbance between the thyrotropin standard 0 and the thyrotropin standard 20 increased from $Q .066$ to 0.143 , therefore enhancing the sensitivity. 'i 


\section{Assay protocol}

Two assay protocols were tested. They differ with respect to the reaction between the thyrotropin in the samples and the antibody coupled to the tube wall (tab. 1). In protocol $A$, the blood spots were incubated with buffer directly in the antibody-coated tubes and the filter paper discs were removed after overnight incubation by decanting during the first washing step. In protocol $B$, the blood spots were first eluted overnight with buffer in an ordinary test tube; thereafter, an aliquot of the eluate was pipetted in the antibody-coated tube. All further steps were identical for both assay protocols.

As shown in figure 1, similar standard curves were obtained with the two assay protocols. The lower absorbance readings of curve $B$ reflect both the shorter incubation time and the smaller sample, which was an aliquot $(500 \mu \mathrm{l})$ of the sample $(600 \mu \mathrm{l})$.

Both assay procedures were run manually as well as with semi-automatic equipment. The latter (ES-22, Boehringer Mannheim), consisted of a dispensingaspirating pump, a tube transport chain, a filter photometer and an Epson HX-20 microcomputer. For end point measumement in the manual assay, we used a LKB-Ultrospec spectrophotometer equipped with a flow-through cuvette (LKB-Autofill). There were no differences in the results of the assays performed manually or with the ES-22.

For all further experiments we decided to use protocol $\mathrm{B}$, since it proved to be more easily adaptable to the ES-22 equipment.

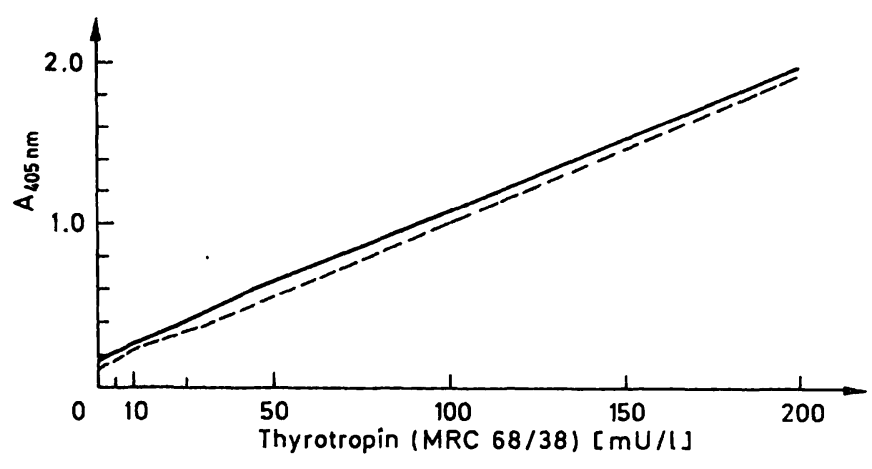

Fig. 1. Standard curves for the blood-spot thyrotropin enzymeimmunoassay obtained after direct incubation of filter paper in antibody coated tubes (incubation of sample aliquots following overnight elution (------).

In our definitive assay procedure, samples or standards, in the form of filter paper discs of $6.5 \mathrm{~mm}$ diameter containing approximately $10 \mu \mathrm{l}$ of dried blood, are incubated overnight at $4{ }^{\circ} \mathrm{C}$ with $600 \mu \mathrm{l}$ assay buffer $\mathrm{A}$ in an ordinary plastic test tube. The following morning an aliquot of the eluate $(500 \mu \mathrm{l})$ is transferred to an antibody-coated test tube together with $500 \mu$ l peroxidase-antibody complex diluted $1: 30$ in assay buffer $B$. All the tubes are briefly shaken and incubated for 3 hours at room temperature. After decanting, the tubes are washed 3 times with tap water, and $1 \mathrm{ml}$ of a mixture of $\mathrm{H}_{2} \mathrm{O}_{2}$ and ABTS is added. After a further 2 hours incubation at room temperature, the absorbance is read at 405 $\mathrm{nm}$ and the results calculated by linear interpolation.

Tab. 1. Asssay protocols for thyrotropin EIA in serum and in dried blood spots.

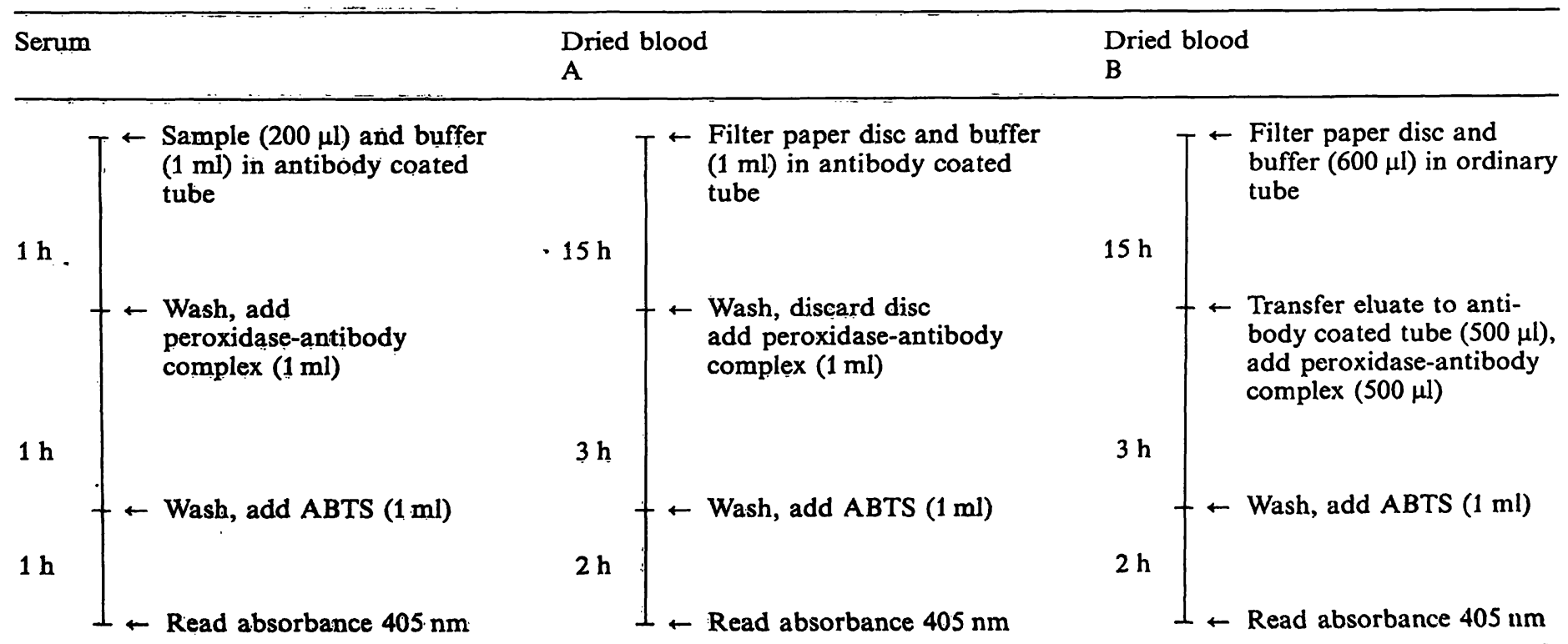




\section{Assay specificity}

According to the data given by the manufacturer (8), the monoclonal anti- $\beta$-thyrotropin antibody coupled to the tube wall has practically no cross-reactivity with either lutropin or follitropin. These results are based on a assay protocol with separate incubation of serum and labelled antibody. However, in our assay procedure $B$, both the tube-bound antibody and the peroxidase-antibody complex were allowed to react simultaneously with the sample eluted from the filter paper. Therefore, we had to test whether high concentrations of lutropin and/or follitropin in the sample would bind a significant amount of the peroxidase-antibody complex thereby decreasing the measured absorbance. In order to avoid this possibility, we decided to increase the concentration of the peroxidase-antibody complex from $1: 50$ to $1: 30$. As shown in table 2 , this excess of enzyme-antibody complex does not disturb the assay, and allows correct measurements of thyrotropin even in the presence of very high levels of gonadotropins.

Tab. 2. Influence of high concentrations of lutropin and follitropin on absorbance (mean, $n=5$ ).

\begin{tabular}{llll}
\hline $\begin{array}{l}\text { Thyrotropin } \\
\mathrm{mU} / 1\end{array}$ & \multicolumn{3}{l}{ Absorbance at $405 \mathrm{~nm}$} \\
\cline { 2 - 4 } & Thyrotropin & $\begin{array}{c}+ \text { Lutropin } \\
200 \mathrm{U} / 1\end{array}$ & $\begin{array}{l}\text { + Follitropin } \\
260 \mathrm{U} / \mathrm{l}\end{array}$ \\
\hline 0 & 0.175 & 0.183 & 0.177 \\
10 & 0.269 & 0.264 & 0.275 \\
20 & 0.358 & 0.361 & 0.359 \\
50 & 0.606 & 0.595 & 0.601 \\
\hline
\end{tabular}

\section{Effect of haemoglobin and bilirubin}

We have tested the effect of haemoglobin in concentrations of $160-270 \mathrm{~g} / 1$. Up to $220 \mathrm{~g} / 1$ (corresponding to a haematocrit of approximately 0.70 ) there was no interference. At haemoglobin concentrations above $250 \mathrm{~g} / \mathrm{l}$ however, a slight increase in absorbance was noticed, which resulted in apparently higher thyrotropin concentrations in the order of $5 \mathrm{mU} / \mathrm{l}$.

In a similarly designed experiment, we tested the influence of foetal haemoglobin by using cord blood samples. There is no interference with the measurement of thyrotropin, even at foetal haemoglobin concentrations as high as $145 \mathrm{~g} / 1$.

In order to test the effect of high concentration of bilirubin, we assayed samples obtained from icteric infants. In blood spots with bilirubin concentrations up to $0.12 \mathrm{~g} / 1$, no interference could be found in the assay. Bilirubin concentrations of $0.2 \mathrm{~g} / \mathrm{l}$ or more, lead to a decrease in absorbance, and therefore to thyrotropin concentrations approximately $30 \%$ to low.

\section{Assay precision}

Intraassay coefficients of variation (CV) at thyrotropin concentrations of 17,57 and $67 \mathrm{mU} / 1$ were $10.9 \%$, $7.5 \%$ and $4.5 \%$ respectively $(n=10)$. Interassay coefficients of variation at the same concentrations were $15.5 \%, 12.9 \%$ and $6.7 \%$ respectively $(n=10)$. The doses read at $20 \%$ and $50 \%$ of the maximal absorbance in 10 consecutive assays were $19.2 \mathrm{mU} / 1 \mathrm{CCV}$ $22.5 \%)$ and $78.5 \mathrm{mU} / 1(\mathrm{CV} 8.0 \%)$ respectively.

\section{Assay sensitivity}

The mean sensitivity of the thyrotropin enzyme-immunoassay in blood spots, read from the standard curve at a point calculated as $A_{o}+2 \mathrm{SD}(7)$, was 3.5 $\mathrm{mU} / 1$. This value was derived from 15 consecutive assays, with a range of results between $1 \mathrm{mU} / 1$ and $7.7 \mathrm{mU} / 1$.

\section{Assay validity}

Blood spot thyrotropin was measured by EIA and RIA in 150 samples of newborn infants collected for routine neonatal thyroid screening. The correlation between the two methods was statistically significant, the correlation coefficient being 0.987 ; the regression equation was $\mathrm{y}=0.42+0.95 \mathrm{x}$ where $\mathrm{y}$ represents the thyrotropin concentration measured by EIA and $x$ the thyrotropin concentration measured by RIA (fig. 2).

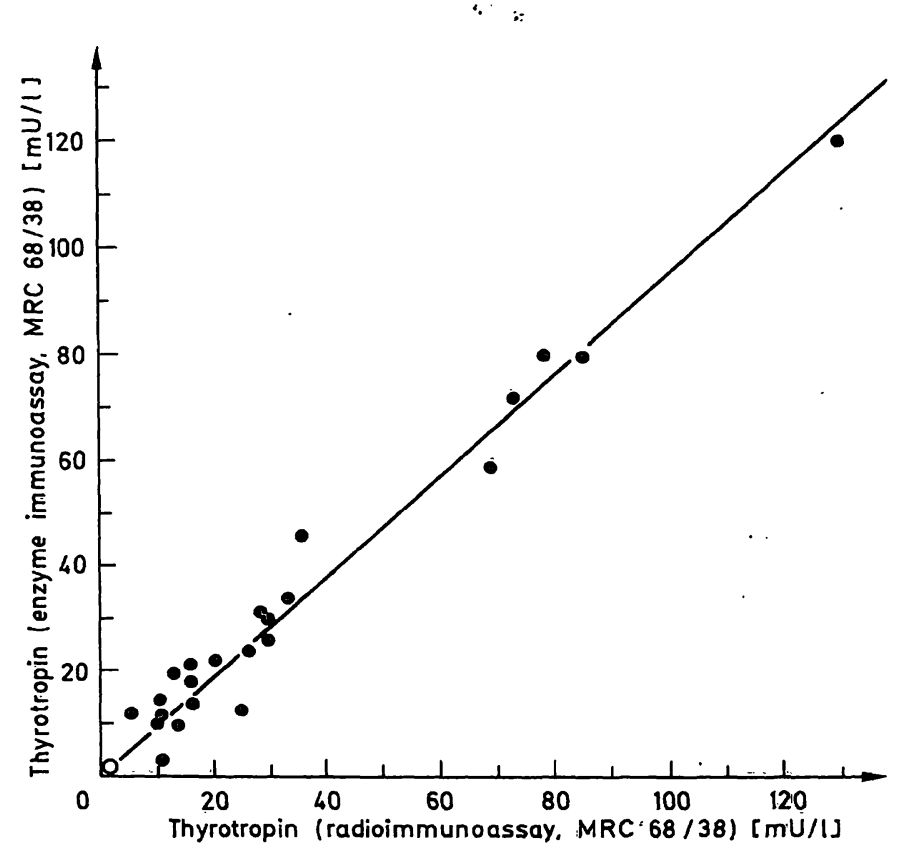

Fig. 2. Correlation of blood-spot thyrotropin concentrations, - measured with RIA (x) and enzyme-immunoassay (y) $y=0.42+0.95 x ; r=0.987 ; n=150$ $\mathrm{O}=$ mean of 111 values $<10 \mathrm{mU} / 1$ 


\section{Discussion}

To our knowledge, this is the first report of an enzyme-immunoassay with photometric end point reading for the determination of thyrotropin in dried blood, although reports on neonatal thyroid screening using enzyme-immunoassay with fluorimetric end point measurement have been published earlier (3).

The combination of a solid phase technique, using a monoclonal antibody, with an enzymatic system consisting of horseradish peroxidase, ABTS and $\mathrm{H}_{2} \mathrm{O}_{2}$, resulted in an assay, which is both fast and sensitive for the measurement of thyrotropin eluted from as little as $10 \mu \mathrm{l}$ of dried blood spotted on filter paper. It is therefore suitable for neonatal thyroid screening.

Furthermore sensitivity, precision and validity of the filter paper EIA compare favorably with those of the RIA used for mass thyroid screening. Assays for neonatal thyroid screening are usually run in series of several hundred samples, and therefore automation of the procedure is highly desirable. However, full automation of the assay is not possible due to the necessity of removing the filter paper before the addition of enzyme-antibody complex, as shown in the results section. With the use of our modified assay protocol, this step is omitted. It is conceivable that also the transfer of an aliquot of eluate may be automated in the near future. In our experience with the filter paper EIA, drifts in results occurred when series of more than 100 tubes were run manually. Such drifts can only be avoided by strict control of the assay procedure during both the pipetting of the substrate and the end point determination. The use of the ES-22 processor facilitated this task allowing an exact control of pipetting and incubation times.

Our results show that the photometric enzyme-immunoassay can be used for the measurement of thyrotropin in dried blood spots. Compared with the original EIA procedure in serum, the sensitivity is reduced, but still adequate for the purpose of neonatal thyroid screening. The longer incubation time, compared with the serum assay, allows us to process daily all the samples received and to report results within 24 hours, therefore resulting in an earlier diagnosis and start of treatment in hypothyroid infants.

The modified enzyme-immunoassay for thyrotropin described in this study requires more pipetting steps than the usual radioimmunoassay and, in addition, a rather time consuming eluate transfer step. However there are considerable advantages, such as the long shelf life of reagents, the possibility of using nonradioactive labels, and the end point measurement with a simple photometer, which make of the EIA assay system a viable alternative to the RIA for the determination of thyrotropin in neonatal thyroid screening.

\section{References}

1. Illig, R., Torresani, T. \& Sobradillo, B. (1977) Helv. Paediat. Acta 32, 289-297.

2. Larsen, P. R. \& Broskin, K. (1975) Pediat. Res. 9, 604-609.

3. Naruse, H., Ishii, S., Kato, N., Tsuji, A., Arakawa, H., Shirane, H., Irie, M., Kunita, N., Takasugi, N. \& Kleinhammer, G. (1983) Neonatal Thyroid Screening with Enzyme immunoassay, In: Neonatal Screening (Naruse, H. \& Irie, M., eds.) Excerpta Medica, Amsterdam pp. 77-82.

4. Torresani, T., Schuster, E. \& İlig, R. (1984) A colorimetric enzyme immunoassay (EIA) for the determination of TSH in dried blood spots: a valid alternative to RIA for neonatal thyroid screening. In: VIIII Intl. Congress of Endocrinology, Quebec 1984, International Congress Series 652, Excerpta Medica, Amsterdam.

5. Bernutz, C., Kewenig, M., Horn, K. \& Pickardt, R. C. (1985) Clin. Chem. 31, 289-292.

6. Watanabe, Y., Amino, N., Tamaki, H., Aozasa, M., Tachi, J., Endo, Y. \& Miyai, K. (1985) Clin. Chem. 31, 634-636.

7. Rodbard, D. (1974) Clin. Chem. 20, 1255-1270.

8. Enzymun-Test TSH, Package insert, Boehringer Mannheim (1984).

Dr. T. Torresani

Universitäts-Kinderklinik

Kinderspital

Steinwiesstraße 75

CH-8032 Zürich 